\title{
The effectiveness of students' preparation in physical training at the universities of various departments
}

\author{
Anvar A. Akhmatgatin ${ }^{1 \mathrm{ABCDE}}$, Vladislav Y. Lebedinsky, ${ }^{1,8 \mathrm{ABCDE}}$, Gennady K. Khomyakov ${ }^{1 \mathrm{ABCDE}}$, Mikhail D. \\ Kudryavtsev ${ }^{3,4,5,6 \mathrm{ABCDE}}$, Alena G. Galimova ${ }^{2 \mathrm{ABCDE}}$, Tatyana L. Kamoza ${ }^{3 \mathrm{BCDE}}$, Evgeniy V. Panov ${ }^{5 \mathrm{BCDE}}$, Vladimir A. \\ Kuzmin ${ }^{3 \mathrm{BCDE}}$, Alexey V. Gaskov ${ }^{7 \mathrm{BCDE}}$, Leonid K. Sidorov ${ }^{6 \mathrm{BCDE}}$, Sergey A. Doroshenko ${ }^{3 \mathrm{BCDE}}$ \\ ${ }^{1}$ Irkutsk National Research Technical University, Russia \\ ${ }^{2}$ East-Siberian Institute of the Ministry of internal Affairs of the RF, Russia \\ ${ }^{3}$ Siberian Federal University, Russia \\ ${ }^{4}$ Reshetnev Siberian State University of Science and Technology, Russia \\ ${ }^{5}$ The Siberian Law Institute of the Ministry of Internal Affair of Russia, Russia \\ ${ }^{6}$ Krasnoyarsk State Pedagogical University of V.P. Astafyev, Russia \\ ${ }^{7}$ Buryat State University, Russia \\ ${ }^{8}$ Irkutsk State University, Russia
}

Authors' Contribution: A - Study design; B - Data collection; C - Statistical analysis; D - Manuscript Preparation; E - Funds Collection

\begin{abstract}
Purpose:

To make a comparative analysis and evaluate the effectiveness of physical exercises in a technical university and departmental university of the Ministry of Internal Affairs of Russia.

Material: $\quad$ The study involved male students ( 1 functional group of health) of the Irkutsk National Research Technical University (Russia, $\mathrm{n}=1380$ ) and cadets of the East Siberian Institute of the Ministry of Internal Affairs of Russia (Russia, $n=762$ ). Cadets studied at 1,2 and 3 courses. The characteristics of physical preparation and the functional condition of students and cadets were analyzed.

Results: $\quad$ During the training period, most indicators of cadets' physical preparation significantly exceed their values in students. This is due to the preliminary selection of candidates for training in educational institutions of the Ministry of Internal Affairs of Russia. It is also associated with a expressed training orientation of the process of physical preparation. The dynamics of the values of the indicators of the functional condition of the body of cadets is characterized by a high price of adaptation to physical activity. This can lead to the occurrence of pre-pathological conditions and pathological processes of the cardiovascular system.

Conclusions: The dynamics of the values of indicators of physical preparation of students and cadets cannot be the only objective criterion for the effectiveness of the system of their physical education. For its full assessment, it is necessary to analyze the parameters of the functional condition of the body, characterizing the reaction to physical activity. Cadets have a great adaptation to physical activity. In this case, it cannot be concluded that the physical training of cadets is more effective.

Keywords: cadets, students, physical preparation, functional condition, physical health.
\end{abstract}

\section{Introduction}

An objective assessment of the pedagogical process effectiveness is a rather complex process. However, this is a necessary element of educational activity for the students' training [1]. Currently, experts from different countries pay a lot of attention to assessing of students' physical education process [2]. It is defined the necessity of solving this very important, ambiguous and problematic problem [3]. The authors emphasize the meaningful role of such an assessment as a tool for improving the success of achieving the training goal [4]. The presence of various functions of physical culture assessments [1] (formative and resulting) [5] is indicated in the publications of foreign experts.

At the same time, a high level of physical health of a future specialist seems to be the most important factor [6]. It is health that ensures the success of subsequent

\footnotetext{
(c) Anvar A. Akhmatgatin, Vladislav Y. Lebedinsky, Gennady K. Khomyakov, Mikhail D. Kudryavtsev, Alena G. Galimova, Tatyana L. Kamoza, Evgeniy V. Panov, Vladimir A. Kuzmin, Alexey V. Gaskov, Leonid K. Sidorov, Sergey A. Doroshenko, 2020 doi:10.15561/20755279.2020.0101
}

professional activities of a specialist [7]. Therefore, the main purpose of physical education for students of higher educational institutions is to strengthen their physical health. This must be done regardless of the majority obtained and the particularities of the organization of the educational process at the university.

For a long time, the effectiveness of physical exercises was determined by the dynamics of the level of students' physical preparation. The reason for this was the leading role of physical labor in the production of material goods. At the turn of the $20^{\text {th }}-21^{\text {st }}$ centuries the situation has radically changed. The main type of professional work has become intellectual activity. It does not impose significant requirements on the level of specialists' physical preparation. A serious consequence of this change was the increased role of hypodynamia. The hypodynamia and environmental degradation led to a decrease in the level of public health.

In this regard, assessing the quality of students' physical exercises only according to the physical preparation is not entirely correct. At the present time, 
it is necessary to analyze the dynamics of students' physical preparation $[8,9]$ to assess the physical exercises effectiveness. It is necessary to use the characteristics of the students' functional condition.

The level of students' physical health can be a full and objective criterion of the physical exercises effectiveness in various educational institutions. The level of physical health is assessed by the physical development of youth. It is also necessary to evaluate the functional condition of the body and the physical preparation of students.

It should be noted that the indicators' values of the human body functional condition are greatly influenced by the conditions of his life. This circumstance includes to cadets at educational institutions that train specialists to ensure law and order. This is due to the fact that students of these universities are engaged in intensive educational activities. They perform official functions that provide a great additional physical and psychological load on their body.

The peculiarities of cadets' of official functions performance should be considered to ensure the effectiveness of the physical preparation process. Moreover, it is known that a rationally organized physical activity provides an increase in the health reserves of cadets. This ensures the success of professional activities. One of the ways to increase the cadets' physical exercises effectiveness is to individualize the training process.

The reaction of the cardiovascular system reflects to a certain extent the features of the adaptation processes course in the human body to any stress factor. Including, when exposed to physical exercises, intense educational activities and other extracurricular factors $[10,11]$.

The purpose of the study is to give a comparative description and evaluate the physical exercises effectiveness in a technical university and departmental university of the Russian Ministry of Internal Affairs.

\section{Materials and methods}

Participants. The study was devoted to the level of physical preparation of male students of the Irkutsk National Research Technical University (IRNRTU, Russia). They belonged to the $1^{\text {st }}$ functional group of health $(n=1380)$. The study involved cadets of the East Siberian Institute of the Ministry of Internal Affairs of Russia (ESI of MIA, Russia, $\mathrm{n}=762$ ). Cadets studied at 1,2 and 3 courses.

The following control exercises were used to determine the level of physical preparation $[6,8]$ :

$-100 \mathrm{~m}$ run (speed abilities);

- shuttle run 10 x $5 \mathrm{~m}$ (coordination abilities);

- pull-up bars (strength abilities);

- Eurofit Sit Up Test for $30 \mathrm{~s}$ (speed-strength endurance);

- Standing Long Jump Test (speed-strength abilities of leg muscles);

- Seated Forward Bend (flexibility);

- $1000 \mathrm{~m}$ run (total endurance).

To assess the functional condition the following methods were used to study indicators of the cardiovascular system [8]:

- heart rate (bpm);

- blood pressure (mm Hg): systolic (SBP), diastolic (DBP), pulse (PP).

The index of blood circulation efficiency (IBCE) was used [12] (formula 1):

$$
\mathrm{IBCE}=\mathrm{PP} / \mathrm{HR} \text { (c.u.) }
$$

where, $\mathrm{PP}$ - pulse pressure; $\mathrm{HR}$ - heart rate.

Pulse pressure is determined by the formula, it is the difference between systolic and diastolic blood pressure:

$$
\mathrm{PP}=\mathrm{SBP}-\mathrm{DBP} .
$$

where, SBP - systolic blood pressure; DBP - diastolic blood pressure.

The physiological meaning of IBCE indirectly characterizes the amount of blood in the human body in the result of one heart contraction. IBCE is significantly more accessible and simple to determine than the systolic discharge.

Design of the study. The study was conducted during the educational process. Physical exercises were carried out according to the work programs of elective disciplines in physical education and sport (students) and the educational discipline "Physical Training" (cadets). The values of the studied indicators were determined twice a year (in September and May) during five academic semesters [13-16]. The conclusions were drawn based on the processing and analysis of the results.

Statistical analysis. The statistical significance of the differences in the average values of the indicators was evaluated by parametric Student t-test $(p<0.05)$.

\section{Results}

The dynamics of the indicators values of students' and cadets' physical preparation during their training are shown in table 1.

In the course of studies in universities, there is a tendency to improve the physical preparation of students $[15,16]$ and cadets. Herein, this tendency is more expressed in cadets. This was especially expressed in the characteristics change of general endurance (1000 m run) (table 1) and flexibility (Seated Forward Bend) (table 1). In each semester, their values in cadets were significantly higher than in students $(\mathrm{p}<0.001)$.

The indicator values of coordination abilities (shuttle run $10 \times 5 \mathrm{~m}$ ) (table 1) in cadets were significantly higher than in students in the $2^{\text {nd }}, 4^{\text {th }}, 5^{\text {th }}$ semesters $(\mathrm{p}<0.05)$.

In the test " $100 \mathrm{~m}$ run" (table 1 ), the results in cadets were significantly higher than in students in the $3^{\text {rd }}$ and $5^{\text {th }}$ semesters $(\mathrm{p}<0.05)$.

Characteristics of self-power abilities (Pull-Up Bars) (table 1) in cadets were significantly higher than in students in the $2^{\text {nd }}$ and $5^{\text {th }}$ semesters $(\mathrm{p}<0.05)$. 
Table 1. Characteristics of the students' physical preparation (1) and cadets (2) in different semesters of study

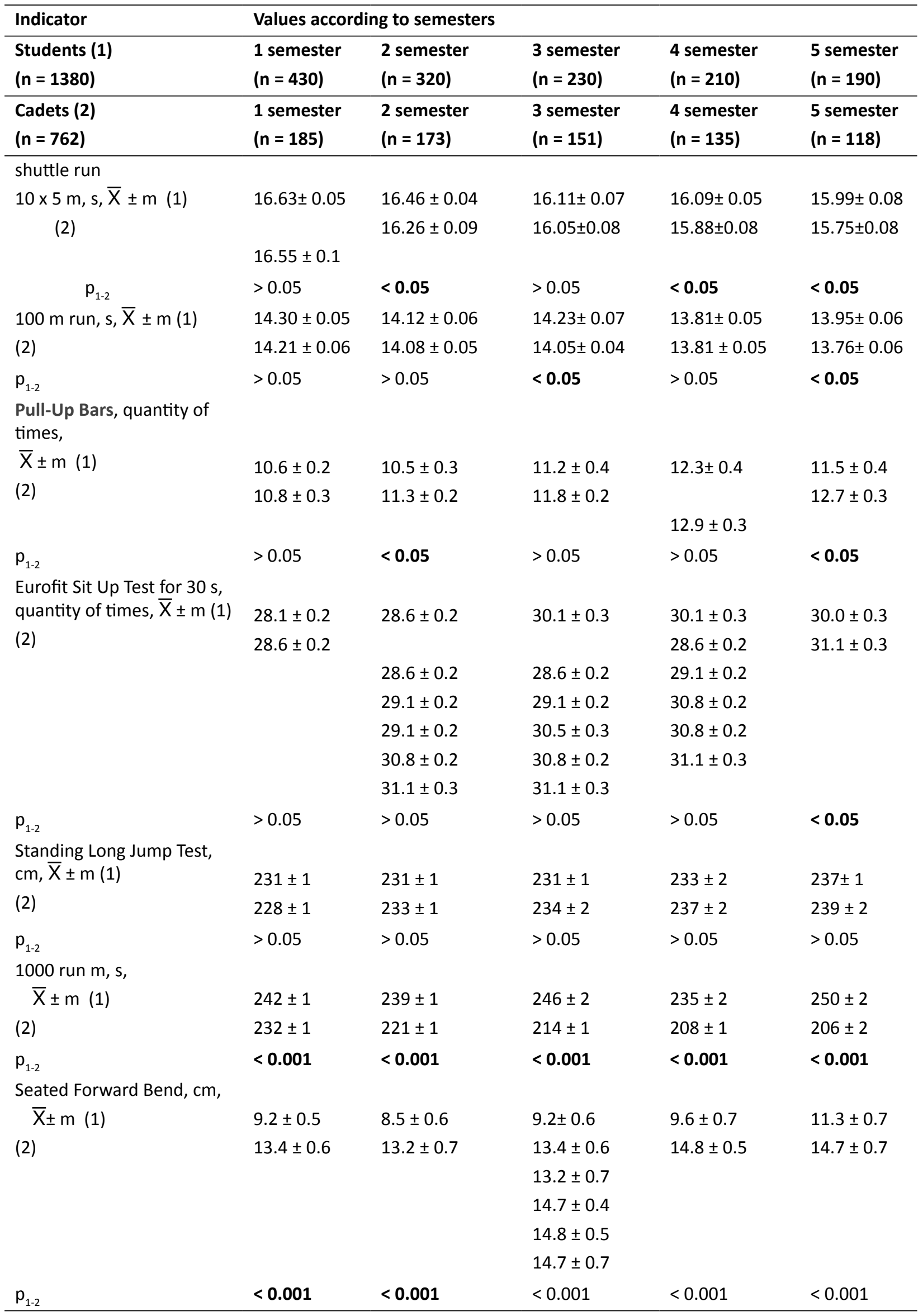


Table 2. Characteristics of the functional condition of students (1) and cadets (2) in different semesters of study

\begin{tabular}{|c|c|c|c|c|c|}
\hline \multirow{2}{*}{$\begin{array}{l}\text { Indicator } \\
\text { Student (1) (n=1242) }\end{array}$} & \multicolumn{5}{|c|}{ Values according to semesters } \\
\hline & $\begin{array}{l}1 \text { семестр } \\
\text { ( } n=337)\end{array}$ & $\begin{array}{l}2 \text { семестр } \\
(n=316)\end{array}$ & $\begin{array}{l}3 \text { семестр } \\
\text { (n= 201) }\end{array}$ & $\begin{array}{l}4 \text { семестр } \\
\text { ( } n=207)\end{array}$ & $\begin{array}{l}5 \text { семестр } \\
(\mathrm{n}=181)\end{array}$ \\
\hline $\begin{array}{l}\text { Cadets (2) } \\
(n=652)\end{array}$ & $\begin{array}{l}1 \text { семестр } \\
(n=150)\end{array}$ & $\begin{array}{l}\text { 2семестр } \\
\text { (n= 136) }\end{array}$ & $\begin{array}{l}3 \text { семестр } \\
(n=130)\end{array}$ & $\begin{array}{l}4 \text { семестр } \\
(n=124)\end{array}$ & $\begin{array}{l}5 \text { семестр } \\
(\mathrm{n}=112)\end{array}$ \\
\hline \multicolumn{6}{|l|}{$\mathrm{HR}, \mathrm{bpm}$, } \\
\hline $\bar{X} \pm m$ & $75.2 \pm 0.5$ & $76.8 \pm 0.5$ & $77.9 \pm 0.5$ & $79.1 \pm 0.7$ & $78.6 \pm 0.8$ \\
\hline$(2)$ & $74.8 \pm 0.8$ & $69.5 \pm 1.1$ & $70.2 \pm 0.8$ & $68.6 \pm 1.0$ & $69.5 \pm 1.1$ \\
\hline$p_{1-2}$ & $>0.05$ & $<0.001$ & $<0.001$ & $<0.001$ & $<0.001$ \\
\hline \multicolumn{6}{|l|}{$\mathrm{SBP}, \mathrm{mm} \mathrm{Hg}$, } \\
\hline $\bar{X} \pm m(1)$ & $130.7 \pm 0.6$ & $134.7 \pm 0.7$ & $134.8 \pm 0.9$ & $137.8 \pm 0.9$ & $137.2 \pm 0.9$ \\
\hline (2) & $133.4 \pm 1.3$ & $126.5 \pm 1.1$ & $125.5 \pm 1.1$ & $128.6 \pm 0.7$ & $127.8 \pm 1.2$ \\
\hline$p_{1-2}$ & $>0.05$ & $<0.001$ & $<0.001$ & $<0.001$ & $<0.001$ \\
\hline $\mathrm{DBP}, \mathrm{mm} \mathrm{Hg}$ & $70.1 \pm 0.4$ & $71.5 \pm 0.5$ & $70.9 \pm 0.6$ & $72.2 \pm 0.5$ & $72.6 \pm 0.6$ \\
\hline $\bar{X} \pm m$ & $84.4 \pm 1.0$ & $79.6 \pm 0.9$ & $80.4 \pm 0.8$ & $80.9 \pm 0.4$ & $77.5 \pm 1.0$ \\
\hline$p_{1-2}$ & $<0.001$ & $<0.001$ & $<0.001$ & $<0.001$ & $<0.001$ \\
\hline \multicolumn{6}{|l|}{$\mathrm{PP}, \mathrm{mm} \mathrm{Hg}$, } \\
\hline $\bar{X} \pm m(1)$ & $60.7 \pm 0.6$ & $63.2 \pm 0.7$ & $63.9 \pm 0.9$ & $65.6 \pm 0.8$ & $64.6 \pm 0.9$ \\
\hline (2) & $49.0 \pm 1.2$ & $46.9 \pm 1.1$ & $45.1 \pm 1.0$ & $47.7 \pm 0.6$ & $50.3 \pm 1.1$ \\
\hline$p_{1-2}$ & $<0.001$ & $<0.001$ & $<0.001$ & $<0.001$ & $<0.001$ \\
\hline \multicolumn{6}{|l|}{ IBCE, c.u. } \\
\hline $\bar{X} \pm m(1)$ & $0.82 \pm 0.01$ & $0.83 \pm 0.01$ & $0.83 \pm 0.01$ & $0.85 \pm 0.01$ & $0.83 \pm 0.01$ \\
\hline$(2)$ & $0.66 \pm 0.01$ & $0.67 \pm 0.01$ & $0.64 \pm 0.01$ & $0.70 \pm 0.01$ & $0.72 \pm 0.01$ \\
\hline$p_{1-2}$ & $<0.001$ & $<0.001$ & $<0.001$ & $<0.001$ & $<0.001$ \\
\hline
\end{tabular}

The level of speed-strength endurance (Eurofit Sit Up Test for $30 \mathrm{~s}$ ) (table 1) in cadets was significantly higher than in students in the $5^{\text {th }}$ semester $(\mathrm{p}<0.05)$.

In other cases, the differences in the indicators values characterizing the level of students' and cadets' physical preparation were not significant $(\mathrm{p}>0.05)$.

The dynamics of the indicators values of the students' functional condition of IRNRTU and cadets of the ESI of MIA of Russia during their training are shown in Table 2.

An analysis of the HR dynamics values (table 2) allowed finding out the following:

- in the $1^{\text {st }}$ semester, differences in the average HR in students and cadets were not significant $(p>0.05)$ at the level of physiological norm;

- in the $2^{\text {nd }}$ semester, the average HR in cadets decreased within the physiological norm and did not significantly change in the future. The average heart rate in students increased. Further the HR did not significantly change and remained also within the physiological norm.

Analysis of the blood pressure values dynamics (table 2) allowed finding out the following:

- SBP value in students during the studied period tended to increase. At the same time, it is significantly decreased in cadets from the $1^{\text {st }}$ to the $2^{\text {nd }}$ semesters. A further change in SBP was not significant. The differences in SBP values in students and cadets in the $1^{\text {st }}$ semester were not significant $(\mathrm{p}>0.05)$, and in the $2^{\text {nd }}-5^{\text {th }}$ semesters the differences were significant $(\mathrm{p}<0.001)$;

- DBP value in cadets decreased significantly. Further until the 4th semester, its changes were not so significant. Only from the 4 th to the 5th semesters DBP values decreased significant. At the same time, DBP value in cadets during the studied period significantly exceeded the same characteristics in students $(p<0.001)$.

- PP value in students from the $1^{\text {st }}$ to the $4^{\text {th }}$ semester tended to increase, and in the $5^{\text {th }}$ semester it decreased. In cadets this characteristic from the $1^{\text {st }}$ to the $3^{\text {rd }}$ semester tended to decrease. Further it increased. At the same time, PP value in students significantly exceeded the same characteristic in cadets during the studied period ( $\mathrm{p}$ $<0.001$ ).

IBCE values (table 2) in students during the studied period ranged from $0.82 \pm 0.01$ c.u. up to $0.85 \pm 0.01$ c.u. The cadets showed a tendency to increase the value of this indicator. The exception was the $3^{\text {rd }}$ semester, in which the average value of IBCE in cadets decreased to $0.64 \pm$ 0.01 c.u. 
Discussion.

The dynamics of indicators determined in the study is associated with the following circumstances:

- at the stage of admission to the educational institutions of the Ministry of Internal Affairs of Russia, applicants undergo a military medical commission and undergo physical training tests, which is combined with the results of other studies [17];

- physical training of cadets of the educational institutions of the Ministry of Internal Affairs of Russia has an applied character. It provides a larger, compared with students of a technical university, amount of physical activity with a training orientation [18];

- the system for assessing academic performance on the discipline "Physical Training" in students of the University of the Ministry of Internal Affairs of Russia imposes significantly higher requirements on the level of physical preparation of students than to technical university students.

The results of our study are coherent with the general statement that cadets' physical preparation indicators significantly exceed the same values in students $[1,2]$. In particular, it concerns the characteristics of general endurance, flexibility, coordination, speed and self-power abilities [3, 4].

Studying the physical preparation process success of young people makes given study even more relevant and sought-after [3, 4]. In this case, the authors' position is coherent with the opinion of foreign experts $[1,5,19]$ in the context of increased motor activity and improving the functional condition characteristics $[8,9,20,21]$; more successful future professional activities of students $[6$, 7]. The results of our study and other specialists indicate the need for changes in physical education curricula for modern young people $[10,11]$

Improving the physical education of young people in higher educational institutions is aimed at increasing the level of their physical preparation $[5,13]$. Therefore, this study does not conflict with general trends in the physical education of students $[14,15,16]$.

The results of our study and a comparative analysis of given indicators complete other studies [17, 18, 22, 23]. They also reveal the reasons that the physical preparation level of cadets exceeds the same characteristics in students. One of the factors for improving the cadets' physical preparation is the fact that many of them are engaged in martial arts.

During the period of study at the university, heart rate values in cadets (except the 1 st semester) were significantly lower than in students $(p<0.001)$. The students' heart rate was a little bit increased but within the physiological norm. The blood pressure changes were characterized by the following features:

- $\quad$ SBP in cadets was significantly lower than in students $(\mathrm{p}<0.001)$ during the study period (except for the first semester). Students' SBP during the studied period tended to increase;

- $\quad$ DBP in cadets during the studied period significantly exceeded the same values in students $(p<0.001)$;

- $\quad$ PP in students during the studied period significantly exceeded the same characteristics in cadets ( $p$ $<0.001)$.

The values of IBCE in students significantly exceeded the same values in cadets $(p<0.001)$ during the studied period. Deviations of IBCE from normal values in cadets are more expressed than in students $[10,12]$. This is since cadets showed an increase in diastolic blood pressure during the studied period compared to students. This characterizes an increase in the tone of the sympathoadrenal system. This increase in diastolic pressure in cadets is associated with high physical activity. This affects the adaptive capabilities of the cadets' bodies. This is accompanied by a constant lack of full recovery and chronic stress. The authors of the article and other experts presuppose that diastolic hypertension can cause pre-pathological conditions and pathological changes in the body of cadets. This can lead to the progression of cardiovascular system diseases in cadets $[12,18]$.

\section{Conclusions}

The study of the physical preparation indicators dynamics and functional condition of students of a technical university and cadets of a departmental university of the Ministry of Internal Affairs of Russia showed that the physical training system of cadets of a departmental university of the Ministry of Internal Affairs of Russia provides a higher increase in physical preparation compared to students of a technical university. Physical activity in cadets is not equal to the adaptive capabilities of their bodies. This can further lead to negative consequences for their health condition. This circumstance does not allow the evaluation of the physical exercise system of cadets from the departmental university of the Ministry of Internal Affairs of Russia as more effective than the similar system of a technical university. Besides, it promotes the further study of the problem of effective assessment of the physical education system of various categories of students.

Conflict of interest.

The authors declare that there is no conflict of interest. 


\section{References}

1. Black P, Wiliam D. Developing the Theory of Formative Assesement. Educational Assesement, Evaluation and Accountability, 2009;21:5-31. https://doi.org/10.1007/s11092-008-9068-5

2. López-Pastor VM, Kirk D, Lorente-Catalán E, MacPhail A, Macdonald D. Alternative assessment in physical education: a review of international literature. Sport, Education and Society, 2013;18:57-76. https://doi.org/10.1080/13573322.2012.713860

3. Thompson D, Penney D. Assessment Literacy in Primary Physical Education. European Physical Education Review, 2015;21(4):485- 503. https://doi.org/10.1177/1356336X15584087

4. Tolgfors B. Different versions of assessment for learning in the subject of physical education. Physical Education and Sport Pedagogy, 2018; 23(3): 311-327. https://doi.org/10.1080/17408989.2018.1429589

5. Borghouts LB, Slingerland M, Haerens L. Assessment Quality and Practices in Secondary PE in the Netherlands. Physical Education and Sport Pedagogy, 2016; 22(5): 473-489. https://doi.org/10.1080/17408989.2016.1241226

6. Akhmatgatin AA, Struganov SM. The characteristics of technical university students physical preparation. Sovremennye problemy nauki i obrazovaniia, 2017; 5:15-21. (in Russian)

7. Leirhaug PE, MacPhail A. It's the other assessment that is the key': three Norwegian physical education teachers' engagement (or not) with assessment for learning. Sport, Education and Society, 2015; 20(5): 624-640, https://doi.org/10.1080/13573322.2014.975113

8. Lebedinskij VIu. The assessment of the physical health of children and teenagers in Irkutsk. Irkutsk: IrSTU Publ.; 2004. (in Russian)

9. Epifanova MG. Monitoring of girl students' physical condition and physical fitness. Irkutsk: IrSTU Publ.; 2014. (in Russian)

10.Ignat'eva EP. Physical condition and physical fitness of third functional health group's students. Irkutsk: IrSTU Publ.; 2014. (in Russian)

11.Izaak SI. Monitoring of physical condition and physical fitness. Moscow: Soviet sport; 2005. (in Russian)

12.Khomiakov GK. Index of efficiency of blood circulation as a method of control for optimization of physical load. Uchenye zapiski universiteta im. P.F. Lesgafta, 2017; 5 (147): 182184. (in Russian)
13.Komkov AG. Social-pedagogic monitoring of physical activity, health and cultural development indicators. Teoriia $i$ praktika fizicheskoj kul 'tury, 1998;6:2-7. (in Russian)

14.Landa BKh. Methodic of physical condition and physical fitness complex assessment. Kazan; 2000. (in Russian)

15.Lebedinskiy VY. Monitoring of HEE educational processes ' subjects health "Health Passport". Irkutsk: IrSTU Publ.; 2008. (in Russian)

16.Lebedinskiy VY. Monitoring of physical health as factor of physical education's pedagogic orientation strengthening in non profile HEEs. Teoriia i praktika fizicheskoj kul'tury, 2014;10:98-101. (in Russian)

17.Hastie PA, Wellhead T. Models-Based Practice in Physical Education: The Case for Sport Education. Journal of Teaching in Physical Education. 2016;35(4):390- 399. https://doi.org/10.1123/jtpe.2016-0092

18.MacLean J, Mulholland R, Gray S, Horrell A. Enabling curriculum change in physical education: the interplay between policy constructors and practitioners. Physical Education and Sport Pedagogy. 2015;20(1):79- 96. https://doi.org/10.1080/17408989.2013.798406

19.Basar MJ, Stanek JM, Dodd DD, Begalle RL. The Influence of Corrective Exercises on Functional Movement Screen and Physical Fitness Performance in Army ROTC Cadets. Journal of Sport Rehabilitation. 2019;28(4):360-367. https://doi.org/10.1123/jsr.2018-0086

20.Borges JH, Hunter GR, Silva AM, Cirolini VX, Langer RD, Pascoa MA, et al. Adaptive thermogenesis and changes in body composition and physical fitness in army cadets. Journal of Sports Medicine and Physical Fitness. 2019;59(1):94-101. https://doi.org/10.23736/s0022-4707.17.08066-5

21.Kukic F, Jeknic V, Dawes J, Orr R, Stojkovic M, Cvorovic A. Effects of training and a semester break on physical fitness of police trainees. Kinesiology. 2019;51(2):161-169. https://doi.org/10.26582/k.51.2.2

22.Orr RM, Dawes JJ, Pope R, Terry J. Assessing differences in anthropometric and fitness characteristics between police academy cadets and incumbent officers. Journal of Strength and Conditioning Research. 2018;32(9):2632-2641. https://doi.org/10.1519/jsc.0000000000002328

23. Vantarakis A, Chatzinikolaou A, Avloniti A, Vezos N, Douroudos, II, Draganidis D, et al. A2-month linear periodized resistance exercise training improved musculoskeletal fitness and specific conditioning of navy cadets. Journal of Strength and Conditioning Research. 2017;31(5):1362-1370. https://doi.org/10.1519/jsc.0000000000001599 


\section{Information about the authors:}

Anvar A. Akhmatgatin; http://orcid.org/0000-0002-4847-0963; ahmatgatin@list.ru; Irkutsk National Research Technical University; Irkutsk, Russia.

Vladislav Y. Lebedinsky; http://orcid.org/0000-0002-5291-8775; lebedinskiy@istu.ru; Irkutsk National Research Technical University; Irkutsk, Russia.

Gennady K. Khomyakov; https://orcid.org/0000-0001-5580-0118; girya-irk60@yandex.ru; Irkutsk National Research Technical University; Irkutsk, Russia.

Mikhail D. Kudryavtsev; (Corresponding author); http://orcid.org/0000-0002-2432-1699; kumid@yandex.ru; Siberian Federal University; Reshetnev Siberian State University of Science and Technology; Krasnoyarsk State Pedagogical University of V.P. Astafyev; The Siberian Law Institute of the Ministry of Internal Affair of Russia; Krasnoyarsk, Russia.

Alena G. Galimova; https://orcid.org/0000-0002-3087-9023; 89027602726@mail.ru ; East - Siberian Institute of the Ministry of internal Affairs of the Russian Federation; Irkutsk, Russia.

Tatyana L. Kamoza; https://orcid.org/0000-0001-9572-5140; tat.kamoza@yandex.ru; Siberian Federal University; Krasnoyarsk, Russia.

Evgeniy V. Panov; http://orcid.org/0000-0002-2724-1854; pan_69@mail.ru ; The Siberian Law Institute of the Ministry of Internal Affair of Russia; Krasnoyarsk, Russia.

Vladimir A. Kuzmin; http://orcid.org/0000-0002-4190-1628; atosn35@mail.ru; Siberian Federal University; Krasnoyarsk, Russia.

Alexey V. Gaskov; http://orcid.org/0000-0003-3076-5429; gaskov@bsu.ru; Buryat State University; Ulan-Ude, Russia.

Leonid K. Sidorov; http://orcid.org/0000-0002-4337-8201; sidorovk@kspu.ru; Krasnoyarsk State Pedagogical University of V.P. Astafyev; Krasnoyarsk, Russia.

Sergey A. Doroshenko; http://orcid.org/0000-0002-8593-1685; trisha246@yandex.ru; Siberian Federal University; Krasnoyarsk, Russia.

\section{Cite this article as:}

Anvar Akhmatgatin, Vladislav Lebedinsky, Gennady Khomyakov, Mikhail Kudryavtsev, Alena Galimova, Tatyana Kamoza, Evgeniy Panov, Vladimir Kuzmin, Alexey Gaskov, Leonid Sidorov, Sergey Doroshenko. The effectiveness of students' preparation in physical training at the universities of various departments. Physical education of students, 2020;24(1):4-10. https://doi.org/10.15561/20755279.2020.0101

This is an Open Access article distributed under the terms of the Creative Commons Attribution License, which permits unrestricted use, distribution, and reproduction in any medium, provided the original work is properly cited http://creativecommons.org/licenses/by/4.0/deed.en

Received: 26.11 .2019

Accepted: 30.12.2019; Published: 04.02.2020 